\title{
The Implementation of Think Pair Share (TPS) Type of Cooperative Learning Model To Improve Student's Motivation And Nutrition Science Learning Achievement
}

\section{Gusti Ayu Made Sukelasmini*}

SMKN 2 Singaraja

\section{A R T I C L E I N F O}

Article history:

Received 19 November 2018

Received in revised form

30 December 2018

Accepted 10 January 2019

Available online 20

February 2019

Keywords:

Nutrition, learning motivation, Think Pair Share

\begin{abstract}
A B S T R A C T
The purpose of this research is to know the increasing of student's motivation and nutrition science learning achievement at second semester Grade $X$ students of SMK N 2 Singaraja Academic Year 2016/2017 after applied the model of Think Pair Share type of cooperative learning model. This research is a classroom action research (CAR). The subjects in this classroom action research are the second semester students of Class $X$ of Tata Boga 5 SMK N 2 Singaraja academic year 2016/2017 which amounts of 41 students. While the object is motivation and student learning achievement. Students' motivational data were collected with observation sheets, while student learning achievement were collected with multiple choice tests. Data analysis used in this research is descriptive data analysis. Based on the research that has been done, it can be concluded that the TPS type cooperative learning model can effectively improve the motivation and learning achievement of Nutrition science at second semester grade $X$ students 5 SMK N 2 Singaraja academic year of 2016/2017. This is evident from the average improvement in student learning motivation in cycle I of 22.10 to 25.22 in cycle II. Classical completeness in cycle I of 82.93 increased to 95.12 in cycle II. While the average increase in student learning results in cycle I was 24.32 increased to 30.41 in cycle II. Classical completeness at cycle I of 78.05 increased to 100 in cycle II.
\end{abstract}




\section{Introduction}

In the era of globalization, education is very important. The development of science, technology and art (IPTEKS) has brought new challenges and opportunities for human kind in its dimension of life, including in the current education sector which has progressed towards a better. Education is an activity of optimizing the development of the potential, skills and characteristics of private learners of educational activities aimed at the achievement of certain goals called education goals (Nana, 2009; 24).

In the world of education it certainly can not be missed from learning activities. Learning is a process of behavior change as a result of an individual's experience. According to Gagne (in Suwatra, et al 2007: 2) "learning is a change in the ability to survive and not from the process of growth". According to Bower and Hilgard (in Suwatra, et al 2007: 2) "Learning is refer to changes in behavior or the potential of individuals as a result of the experience and those changes are not caused by instinct, maturity or fatigue and habits". According to Behavioristic Theory (in Suwatra, et.al., 2007: 19) "learning is a change of human behavior that is heavily influenced by environmental factors that will provide a variety of experiences to a person, in particular the capacity of a new (behavioral) student as a result of interaction with the environment, maturation process. "To achieve optimal learning outcomes, learning must be supported by a conducive learning environment. The learning process as one of the key elements in education at SMK (Vocational High School) has a large role in mediate and accommodate efforts to improve the thinking and skills of the participants in the training towards positive behavioral change (Sabil, 2014). The learning process that emphasizes the empowerment of training participants should be done in every teaching and learning process at SMK, as mandated by Law No. 20 Year 2003 Chapter 2 Article 3 on the functions and objectives of national education, that the education process should be organized with the orientation of culture, empowerment, character formation and personality, and various life skills. This becomes very substantial when challenges in the era of globalization are becoming increasingly real and complex. The lessons in SMK are implemented within the framework of the establishment of Graduates Competency Standards (SKL) students. Learning at SMK uses outcome paradigms of what competencies must be mastered in learning rather than imposing what teachers need to teach.

The phenomenon in the field indicates that the learning process in SMK has a counterproductive tendency with the above expectations. This can be seen in some studies on the learning process at SMK (Rusyana, 2006) which illustrates that the process is monotonous or there is no variation, centered on teachers, and involves less active participation of the training participants. The study is in line with the view of Purba (Kompas, 2006) which states that '... the reality of learning at SMK still puts face to face in the classroom. In fact, not a few educators in a number of SMKs, both technology and industry who are not taught the real practice. As well as learning done at SMKN 2 Singaraja. This SMK includes many SMKs who are interested in the quality of education in SMK that are quite good, but based on observations conducted by SMK researchers, researchers found that in the process of learning Nutrition, teachers still use the lecture method so that teachers can not bring their students closer with their learning experience and students still lacking in critical thinking skills, creativity, and constructing knowledge. The role of teachers in the classroom is still very dominant and the involvement of students in the learning process is very limited, so learning is still one way. Class conditions are quite crowded because when teachers talk, there are some students who often get back, sick leave, own stories in the classroom, and even some sleepy ones. This is because the learning model used by the teacher is less interesting for students to learn. This problem leads to the low motivation of learning and negatively impacting student learning outcomes. This is reflected in the average student learning outcomes in Nutrition subjects of 73.58 under the MOH set by the school of 80 .

One of the efforts that can be done to address the problem is, by applying a Think Pair Share (TPS) cooperative learning model. According to Sanjara, (2013) TPS is a kind of cooperative learning designed to influence student interaction patterns. After presenting a brief enough material the students are expected to think of a more profound task then discuss the answer (Septriana, 20116). The Think Pair Share (TPS) cooperative learning model is a learning model that gives students more time to think, respond, and help each other or collaborate with other students "(Ibrahim, 2000). The Think Pair Share (TPS) cooperative model provides students with the opportunity to work on their own and to work with others.

ThinkPair Share (TPS) cooperative learning model has the following principles: 1) goal-oriented, 2) activity, 3) Individuality, 4) integrity. This Think Pair Share (TPS) learning model is included in cooperative learning. Co-operative learning is one of the group learning models that have certain rules. The basic principle of cooperative learning is to create small groups and teach each other to achieve common goals. In cooperative learning the clever students teach students less clever without feeling 
disadvantaged. Less talented students can learn in a fun environment because many friends help and motivate them. Students who have been accustomed to being passive after using cooperative learning will be forced to participate actively in order to be accepted by their group members.

Based on the above presentation, this study will take the title on the application of ThinkPair Share (TPS) cooperative learning model to improve the motivation and learning outcomes of Nutrition Science students of second semester Class X Tata Carta 5 SMK N 2 Singaraja Academic Year 2016/2017.

\section{Method}

This research was conducted at the second semester in SMKN 2 Singaraja academic year 2016/2017. The research was conducted from February to May 2017. In this study, the subject of the research was the second semester students of Class X Tata Cil 5 SMK N 2 Singaraja Pelajaran Tahun $2016 / 2017$ which amounted to 41 students. While the object of this research is the student's motivation and result of learning Nutrition after following the TPS learning model.

In this research, the researcher chooses the design that is in accordance with the research that is done class action research (PTK). This class action study was conducted in order to solve a problem experienced by a teacher while teaching in the classroom. This study will consist of two cycles to improve the process and learning outcomes. The improvement of the quality of the learning process in this study was carried out in the subjects of Nutrition in Grade X Tata Cawangan 5 SMK N 2 Singaraja. According to Agung (2014: 139) "Each cycle consists of four phases: planning, action, observation / evaluation and reflection."

1. Planning

Action planning includes: 1) Preparing the implementation plan of learning according to competency standards, basic competencies and predetermined indicators, and 2) preparing student learning motivation assessment instruments.

2. Action Implementation Implementation of actions performed each cycle is done 3 times the meeting. Each meeting is conducted in accordance with the procedures that have been drafted on the RPP.

3. Observation / Evaluation

In this observed activity are: a) Observing the learning process, and 2) Assessing students.

4. Reflection

Reflection is done to reflect on and evaluate the results of action on cycle I on the motivation of learning the Nutrition of students.

In this class action study (PTK) it refers to the theory proposed by Kemmis and Taggrat (in Agung, 2014: 140). This research model has four phases in one cycle of the four phases of research according to the ones described above. This cycle can be described as follows.

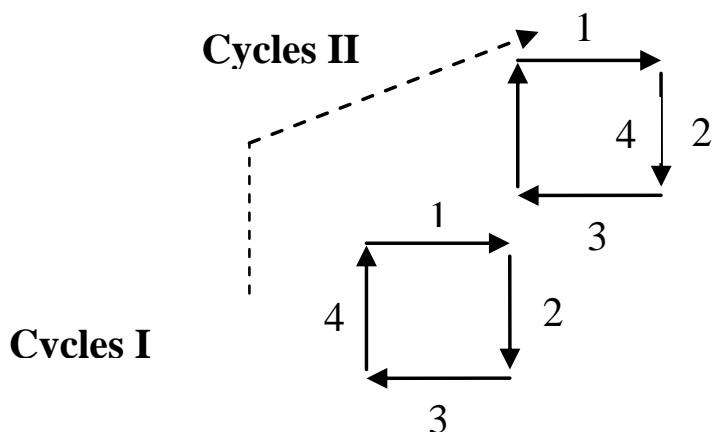

Picture 01. Two Model of PTK (Agung, 2014: 141)

Description:

1. Stage planning

2. Stage of action

3. Stage of observation / evaluation

4. Reflection stage

In this study, observation methods are used to collect data on student learning motivation. While the test method is used to collect student learning result data. The data obtained are scores. After data in 
this research collected then conducted data analysis. There are two types of statistical analysis methods that are descriptive statistical analysis methods and inferential statistical analysis methods.

The indicator of the success of this implementation, is based on the following criteria. The success rate in this study is if the average motivation and student learning outcomes are minimal in the High category, and the classical completeness is $\mathbf{9 0 .}$

\section{Results and Discussion}

The Think Pair Share (TPS) learning model grew from cooperative learning research. ThinkPair Share Model (TPS) was first developed by Frank Lyman, et al from the University of Maryland in 1985. The Think Pair Share (TPS) model is one part of the structural approach. "ThinkPair Share Learning Model (TPS) is a learning model that gives students more time to think, respond, and help each other or collaborate with other students" (Ibrahim, 2000). The Think Pair Share (TPS) model gives students the opportunity to work on their own and to work with others. The ThinkPair Share Share (TPS) stages include: Thinking, Pairing (pairing), Sharing (sharing) (Ibrahim, 2010). In the Thinking phase, the teacher asks questions or issues related to the lesson, then students are asked to think about the answer to the question or issue independently for a while. At this stage students are required to develop cognitive aspects ie by remembering and understanding the material already submitted. Thinking independently is one of the efforts to give responsibility to each individual student (Winayah, 2013).

At Pairing stage, the teacher asks students to pair up with other students to discuss what has been thought at the stage of Thinking. At this stage, each student expressed his idea, giving feedback and response, and at the end of the discussion it was hoped that they could formulate a joint conclusion to be delivered at the next stage. In this stage the affective sap in the individual is very prominent. This is seen by the willingness of students to join their spouses. Complete the task given by the teacher and participate actively in the discussion with his partner. The main thing that is expected to be achieved in this stage is the unification of values, concepts and ideas.

S

Next in Sharing stage, the teacher asks each partner to share with the whole class about what they have done at the stage of pairing. This stage will be affective if implemented by assigning each partner in turn to present the results of their discussion in front of the class. These stages emphasize on the ability to perform or perform students' performance in presenting the results of their group discussion in front of the class. Expressing ideas, listening to the opinions of friends, and working together to build understanding or concepts is very important in learning because it can foster student learning motivation.

The application of the Think Pair Share (TPS) learning model gives students more time to think, answer, and help each other (Wahyuni, 2013). In this study, students share with all the students in the class about what they have discussed. Students are given the opportunity to express their thoughts in accordance with the material being discussed, solve problems according to their ideas, communicate, and learn from their friends' ideas. All students' answers should be appreciated so that they dare to express their opinions and ideas. Learning to explain, listen to and judge other students's opinions and comment on other students's ideas is an opportunity to increase their understanding of the issues being discussed. This activity can also help develop language skills in expressing their ideas. Through these activities the students feel really involved in the learning and the involvement will make the students happy to learn and can improve their motivation and learning outcomes.

Based on the research conducted by applying a TPS type cooperative learning model it was found that: in the average cycle of Student's Motivation motivation $=22.10$, after being enrolled into the five-PAP scale, was at a score interval of $20<\mathrm{X} \leq 24$ meaning that the level of Motivation to study Nutrition of students in cycle I is quite high. However, it is seen from its classical completeness $=82.93 \%$. That is because 7 students have the motivation to learn Nutrition of moderate nutrition, 29 students have the motivation to learn Nutrition is high, and 5 students have a very high motivation to learn Nutrition.

While the results of study on nutrition students in cycle I get an average of 24.32 , after being converted into five-scale PAP, is at interval of $\mathrm{X}$ score of $23.33<\mathrm{X} \leq 30$ which means that the level of learning result of Nutrient Science of cycle II student belongs very high. Viewed from its classical completeness, it is obtained by classical completion of $=100 \%$. This is because the students who have the learning achievement in the category are 9 students, and the students who have the learning outcome at high category of 32 students.

There are still students with motivation and learning outcome of Nutrition which are still classified as being, because there are some students less active in group activities. In addition, students are still less confident in expressing opinions and conclusions from their group discussion in front of the class. 
In the second cycle of the average Motivation study of Nutrition of students $=25.22$, after being enrolled into the five-scale PAP, was at intervals of X> 24 which meant that the level of Motivation to study the Nutrition Science of the cycle II students was very high. Based on its classical completeness, it is obtained by classical completeness of $=95.12 \%$. This is because students with moderate motivation are 2 students, students who have high motivation as much as 15 students, and students who have very high motivation as much as 24 students.

While the results of the study were on the average of 30.41 students, after being deposited into the five-scale PAP, at the interval of $X>30$ which means that the level of learning results from the Nutrition Science of the cycle II students is very high. From its classical completeness, it is obtained by classical completion of $=100 \%$. This is the student who has a learning achievement in the high category are 23 people, and the students who have learning the result are very high as much as 18 people.

These results indicate that the constraints faced in the first cycle can be overcome in cycle II. So from that minimum high completeness criteria with a minimum of $90 \%$ completeness have been fulfilled so that the research in the second cycle was declared successful and the cycle was stopped.

For more details, the results of this study can be illustrated in the following histogram.

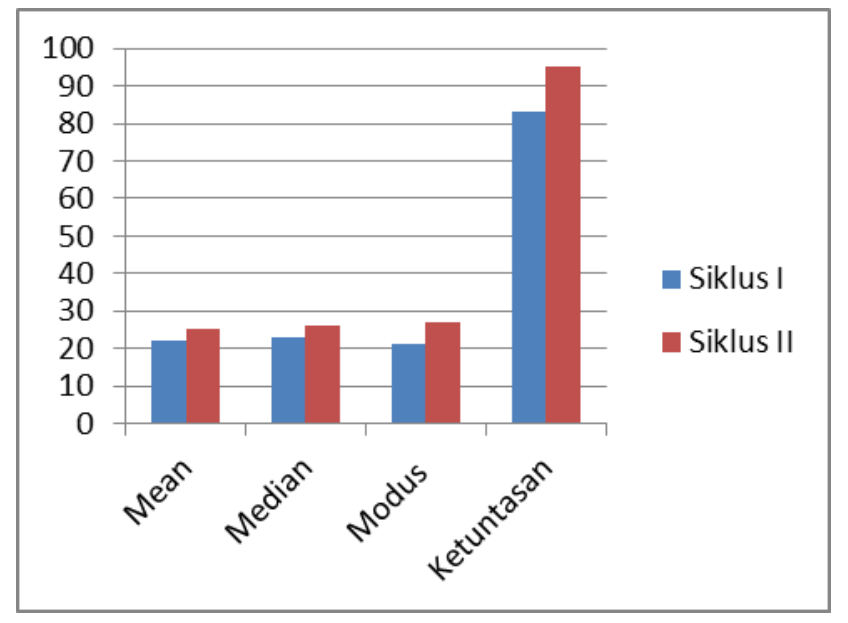

Picture 02. Increased Student Learning Motivation from Cycle I to Cycle II

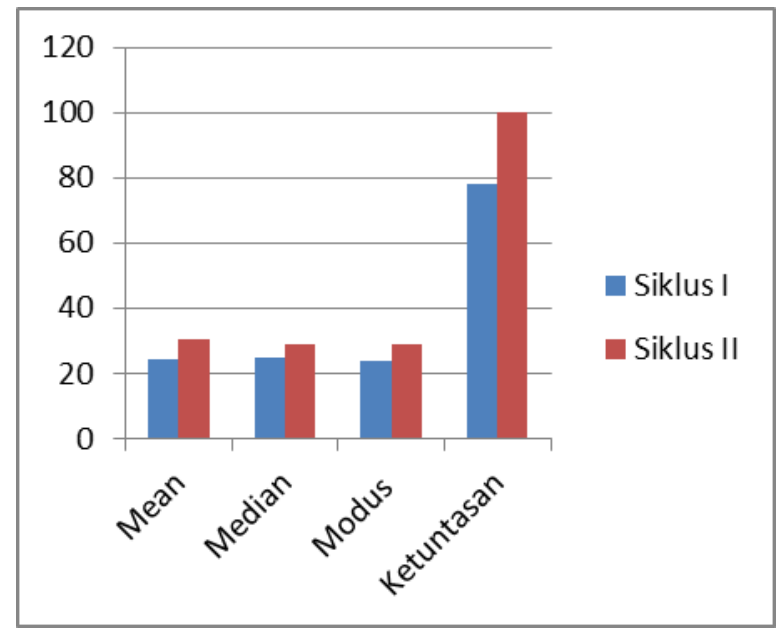

Picture 03. Increasing Student Learning Outcomes from Cycle I to Cycle II

The results of this study are in line with the results of research conducted by Dewi (2013) with the research title applying the Think Pair Share (TPS) method structural approach to circle material to improve students' mathematics learning activities. The results of the study show that the application of the TPS method structural approach to the learning of mathematical circle material can significantly improve students' mathematics learning activities. Students are given the opportunity to think about and solve problems about circles with their partners. The success of student mathematics learning activities 
can be realized through a process of communication between students and teachers and students with other students.

\section{Conclusions and Suggestions}

Based on the research that has been done, it can be concluded that the TPS type cooperative learning model can effectively increase the motivation and learning outcomes of Nutrition Science in second semester class X of Catering 5 Singaraja Vocational High School 2 2016/2017 Academic Year. This can be seen from the increase in the average student learning motivation in the first cycle of 22.10, increasing to 25.22 in the second cycle. Classical completeness in the first cycle of 82.93 increased to 95.12 in the second cycle. While the increase in average student learning outcomes in the first cycle of 24.32 increased to 30.41 in the second cycle.

Classical completeness in the first cycle of 78.05 increased to 100 in the second cycle. Suggestions that can be submitted from the holding of this research are as follows: 1) Students should take learning seriously and always increase their learning motivation, so that learning becomes active and easy to understand, 2) The teacher should always provide a place of learning that supports the improvement of student learning motivation, so that the learning outcomes will be improved and the planned learning goals can be achieved optimally, 3) The principal should always make decisions that support the academic and student improvement. Other researchers are expected to develop this research by using more complex variables, so that the problems that occur in learning in schools can be minimized.

\section{References}

Agung, A. A. Gede. 2011. Metodologi Penelitian Pendidikan. Fakultas Ilmu Pendidikan Institut Keguruan dan Keilmuan Negeri Singaraja.

Agung, A. A. Gede. 2014. Metodologi Penelitian Pendidikan. Singaraja: Undiksha.

Azizah. 2013. "Penerapan Pendekatan Struktural Metode Think Pair Share (TPS) Pada Materi Lingkaran Untuk Meningkatkan Aktivitas Belajar Matematika Siswa “. Tersedia pada e-Journal Program Pascasarjana Universitas Pendidikan Ganesha Program Studi IPA Volume 7 Tahun 2013.

Ibrahim, M, dkk. 2000. Pembelajaran Kooperatif. Surabaya: University Press.

Ibrahim, A. Rachman. 2010. Upaya Meningkatkan Hasil Belajar Mahasiswa melalui Penerapan Model Pembelajaran Think Pair and Share pada Mata Kuliah Kimia Dasar 1. Forum MIPA, 13(2):77-81.

Indriasih, Aini. 2014. Pembelajaran Kooperatif Model Think Pair and Share sebagai Inovasi Pengajaran IPS di SD. Universitas Terbuka UPBJJ-UT Semarang, 40(1):72-85.

Jannah, Rikhinati, A. N. C. Saputro, \& S. Yamtinah. 2013. Penerapan Model Pembelajaran Think Pair Share (TPS) Disertai Buku Saku untuk Meningkatkan Aktivitas dan Prestasi Belajar Kimia pada Materi Minyak Bumi Kelas X SMA Negeri Gondangrejo Tahun Pelajaran 2012/2013. Jurnal Pendidikan Kimia (JPK), 2(4):19-23.

Jayadiningrat, Made Gautama, I. Nyoman Tika, dan Ni Putu Yuliani. "Meningkatkan Kesiapan Dan Hasil Belajar Siswa Pada Pembelajaran Kimia Dengan Pemberian Kuis Di Awal Pembelajaran." Jurnal Pendidikan Kimia Indonesia 1.1 (2017): 7-12.

Muthoharoh, Munifatun, I. Made Kirna, and Gusti ayu Indrawati. "Penerapan Lembar Kerja Peserta Didik (LKPD) Berbasis Multimedia untuk Meningkatkan Motivasi dan Hasil Belajar Kimia." Jurnal Pendidikan Kimia Indonesia 1.1 (2017): 13-22.

Rusyana, Yus.2006. Peranan Tradisi Lisan dalam Ketahanan Budaya. Jakarta: Direktorat.

Sanjaya, Bratanata, Mustika Wati, dan Syubhan An'nur. 2013. Meningkatkan Hasil Belajar Siswamelalui Penerapan Pembelajarankooperatif Tipe Think Pair-Share (TPS). Berkala Ilmiah Pendidikan Fisika Vol.1, Nomor 3. 
Sabil, Husni. 2014. Meningkatkan Hasil Belajar melalui Pembelajaran Kooperatif Tipe ThinkPair-Share pada Materi Penampang dan JaringJaring Mahasiswa Program Studi Pendidikan Matematika FKIP Universitas Jambi. Edumatica, 4 (1):23-29.

Septriana, N. \& B. Handoyo. 2006. Penerapan Think Pair Share (TPS) dalam Pembelajaran Kooperatif untuk Meningkatkan Prestasi Belajar Geografi. Jurnal Pendidikan Inovatif, 2(1):47-50.

Sudjana, Nana, 1990. Penilaian Hasil Proses Belajar Mengajar. Bandung: PT. Remaja Rosdakarya offset.

Suwatra, dkk. 2007. Modul Belajar dan Pembelajaran. Singaraja: UNDIKSHA.

Wijayanto, Zainnur. 2015. Eksperimentasi Model Pembelajaran Kooperatif Tipe Think Pair Share (TPS) Dengan Pendekatan Open-Ended Ditinjau Dari Disposisi Matematis Siswa Kelas VIII SMP Negeri Di Kabupaten Purworejo. Jurnal Ilmiah Pendidikan Matematika, Vol. 3, No. 2.

Wahyuni \& R. Hasanah. 2013. Pengaruh Penerapan Metode Eksperimen Dengan strategi TPS (Think Pair Share) dalam Model Pembelajaran Diskusi Terhadap Hasil belajar Siswa Pada Materi Perpindahan Panas Di Kelas VII SMP Negeri 2 Buduran Sidoarjo. Jurnal Inovasi Pendidikan Fisika, 2(3):89-94.

Winayah, I. R., Sudarti, \& Nuriman. 2013. Penerapan Model Pembelajaran Kooperatif Tipe Think Pair Share dengan Metode Praktikum dalam Pembelajaran IPA Fisika Kelas VIII B SMPN 7 Jember Tahun Pelajaran 2012/2013. Jurnal Pembelajaran Fisika, 1(4). 